\title{
THE RENDITIONS PRODUCED BY THE INTERPRETERS IN SERMON INTERPRETING AT ROCK CHURCH DENPASAR BALI
}

\author{
Johnli Hervie Lumi ${ }^{1}$, I Made Suastra ${ }^{2}$, Ida Ayu Made Puspani ${ }^{3}$ \\ Universitas Papua, Email: hervie77@gmail.com ${ }^{1}$, madesuastra@ yahoo.co.id ${ }^{2}$, \\ dayupuspani@yahoo.com ${ }^{3}$ \\ Universitas Udayana ${ }^{2,3}$
}

\begin{abstract}
This paper explores the renditions produced by the interpreters in sermon interpreting at ROCK Church Denpasar Bali. It aims at finding out and investigating the categories and the motives of the renditions produced by the interpreters in the setting under investigated. The method adopted for this study is a descriptive qualitative approach. The data of this study is based on six transcribed audio-video recordings of interpreter-mediated sermons on Sunday services, involving six visiting preachers, congregation, and three interpreters. The sermons are preached in English and interpreted short-consecutively into Indonesian. The data were collected through observation method which was applied at once with the implementation of note-taking technique, and were analyzed using the qualitative method and comparative technique. As a theoretical framework, the taxonomy of renditions proposed by Wadensjö (1998) has been utilized. The result of the study shows that there were eight categories of rendition produced by the interpreters in sermon interpreting on Sunday services at ROCK church Denpasar Bali. The categories of rendition produced by the interpreters were close renditions, expanded renditions, reduced renditions, substituted renditions, summarized renditions, two-part renditions, nonrenditions, and zero renditions.
\end{abstract}

Keywords: rendition, interpreter, sermon interpreting, church 
LINGUISTIKA, MARET 2019

p-ISSN: 0854-9613

Vol. 26. No. 1

Abstrak-Tulisan ini mengkaji tentang produk terjemahan lisan yang diproduksi oleh para penerjemah lisan dalam penerjemahan khotbah di gereja ROCK Denpasar Bali. Tujuan dari penelitian ini untuk menemukan dan menganalisa kategori-kategori terjemahan lisan (renditions) yang diproduksi oleh para penerjemah lisan, beserta penyebab terjadinya hasil terjemahanterjemahan lisan tersebut. Penelitian ini dilakukan dengan menerapkan metode penelitian kualitatif dimana pembahasan disajikan dalam bentuk deskriptif. Data dalam penelitian ini didapatkan dari enam rekaman audio-video khotbah Mingguan, yang melibatkan enam penghotbah tamu, jemaat, dan tiga penerjemah lisan. Khotbah disampaikan dalam bahasa Inggris dan diterjemahkan secara konsekutif singkat ke bahasa Indonesia. Data tersebut dikumpulkan dengan menggunakan metode observasi, serta di dukung dengan penerapan teknik pencatatan, dan dianalisis secara deskriptif dengan menggunakan metode kualitatif dan teknik komparatif. Permasalahan dalam penelitian ini dianalisa dengan menggunakan taksonomi terjemahan lisan yang dikemukakan oleh Wadensjö (1998). Hasil analisis menunjukkan bahwa terdapat delapan kategori ujaran yang diproduksi oleh para penerjemah lisan dalam penerjemahan khotbah Mingguan di gereja ROCK Denpasar Bali. Adapun kategori-kategori hasil terjemahan lisan (renditions) yang diproduksi oleh para penerjemah adalah terjemahan dekat (close renditions), terjemahan yang diperluas (expanded renditions), terjemahan yang dikurangi (reduced renditions), terjemahan yang diganti (substituted renditions), terjemahan yang diringkas (summarized renditions), terjemahan terbagi dua (two-part renditions), bukan hasil terjemahan (non-renditions), dan tidak diterjemahkan (zero renditions).

Kata kunci: hasil terjemahan lisan, penerjemah lisan, penerjemahan lisan khotbah, gereja 


\section{INTRODUCTION}

In the past, the activity of interpreting was associated with the world of diplomacy and international conferences. Today, with the increase of relations and global mobility between people of different languages and cultures, the demand for interpreters and interpreting services in various cross-linguistics and cross-cultural situations in all across the world has increased more than ever before. Interpreting has become an important bridge in bilateral exchanges and relations in many settings that requires communication between speakers of different languages, be it in formal or informal settings (Pöchhacker, 2004: 13-18).

In Indonesia, Bali particularly, interpreters and interpreting services are not only needed in international conferences and seminars, such as The 2013 APEC Summit Conference and Co-Operative Alliance Asia-Pacific Conference, but also in various settings in the community, such as proceedings in Denpasar Court, involving foreigners as witnesses or defendants, and in many informal settings, such as interpreting for business matters and for tourists.

This also applies to the interaction between preachers and congregation on Sunday services at ROCK Church Denpasar Bali, which became the point of this study. In this context, most of the sermons on Sunday services are conducted in Indonesian with local pastors or leaders. This means they do not rely on interpreters in conveying the sermons to the congregation. Yet, on certain occasions, when the sermons are delivered by a visiting preacher from abroad who does not speak Indonesian, the presence of an interpreter is required.

On such occasions, the role of an interpreter is very important because the visiting preacher is a person who does not speak Indonesian and the congregation consisted of people who either do not understand the preacher's language or who are limited in their understanding. The congregation had to rely on the interpreter to access the sermon, while the preacher is very dependent upon the interpreter's ability in relaying the message to the congregation. Without the presence of an interpreter, the preacher's sermon cannot get across to the entire congregation, but just to a few in the congregation who would be able to understand the message without interpretation.

The primary concern of an interpreter is basically to make sense what a speaker was saying and then communicates the message to the listeners/audience using the language they understand, so that the communication process becomes successful (Wadensjö, 1998:7). Nevertheless, interpreting is a communicative process that proves to be a difficult and challenging task for those involved and is not easy as people might think. Studies have shown that there are many cases when interpreter's renditions diverge from original utterances due to specific challenges faced in interpreting. As a result, the interpreter has to make different decisions regarding to his renditions most of the time, resulting in inconsistencies in the way the interpreters dealt with original utterances.

Bearing in mind that even though interpreting has been practiced in the religious settings for a long time. Yet, there are rarely research efforts on interpreting in the church settings. This study, therefore, attempts to fill the gap by examining the product of the interpreters at ROCK Church Denpasar Bali. This paper investigated the following question: What are the categories and the motives of occurrences of the renditions produced by the interpreters in sermon interpreting at ROCK Church Denpasar Bali. It is hoped that this study will contribute to our further understanding of an interpreter-mediated interaction, in particular, sermon interpreting at church setting which has rarely been the focus of research attention.

\section{RESEARCH METHOD}

The approach adopted in this study is descriptive qualitative method. Moleong (2004: 4) states that qualitative research has a natural setting as a data source or in the context of an 
entity. The data on which the study is based on is six audio-video recordings of interpretermediated sermons on Sunday services at ROCK Church Denpasar Bali, recorded between 20102012, involving six visiting preachers, congregation, and three interpreters. The data were collected through observation method which was applied at once with the implementation of note-taking technique (Sudaryanto, 1993: 137).

For the purpose of this study, the data recordings were observed by watching, listening and subsequently transcribed orthographically both the English source texts and Indonesian target texts for the analysis. The data were analyzed by comparing the interpreters' renditions against the originals in order to identify the categories and the motives of the renditions produced by the interpreters. The data were analyzed by using the qualitative method and comparative technique based on the problems of the study (Olohan, 2004:1 10). The analysis was principally guided by Wadensjö's model of renditions (1998). The results were presented by using informal method in the form of words and explanations rather than symbols (Sudaryanto, 1993: 145).

\section{DISCUSSION}

In this section we described the categories of renditions identified in our analysis, and discussed the motives of the occurrence of the renditions, with reference to representative examples from the data.

\section{Close renditions}

One of the frequently occurring rendition categories observed in the data is close renditions. Close rendition refers to the interpreter's output in which the propositional content of the original utterance found explicitly expressed in the rendition, and the style of the two utterances is approximately the same (Wadensjö, 1998:107). This category of renditions could be considered as being equivalent to source utterances. The interpreters output in the data of this study shows that close renditions mostly occurred when the preacher's utterances are short and simple, and conveyed with a clear flow of thought.

Excerpt 1 (Sermon 4, minutes 13:33 - 13:58)

1 PR : Thank You God

2 INT : Terima kasih Tuhan

3 PR : Dear Father

4 INT : Bapa yang baik

$5 \mathrm{PR}$ : Touches every person this morning

6 INT : Jamahlah setiap pribadi pagi hari ini

7 PR : In Jesus wonderful name

8 INT : Dalam nama Yesus yang ajaib

Excerpt 1 above is an example of close renditions produced by the interpreters in the data. As we can see, in turn 1, the preacher says "Thank You God", and it is immediately rendered in turn 2 by the interpreter as "Terima kasih Tuhan". The original utterance in turn 1 is basically a sentence that has a construction consisted of a predicate (Thank), object (You), God (complement), and its rendition consisted a predicate (Terima kasih), object (Tuhan). Therefore, comparing (2) with (1) could be called as close rendition, with a slight adjustment to the form.

The interpreter's next utterances look fairly close as well, in particular if we understand the adjustment made by the interpreter to some words of the originals. In turns 3 and 5 respectively, the preacher says, "Dear Father", "Touches every person this morning", and it is immediately rendered with close renditions in turns 4 and 6 as, "Bapa yang baik", "Jamahlah setiap pribadi pagi hari ini". The original utterances in turns 3 and 5 above are basically a complete sentence that has a construction consisted of a subject (Dear Father), predicate (touch), object (every person), adverbial (this morning), and its rendition in target language consisted of subject (Bapa yang baik), predicate (jamahlah), object (setiap pribadi), adverbial (pagi hari ini). Therefore, comparing (4) and (6) 
with (3) and (5) could be considered close as well.

Lastly, in turn 7, the preacher says, "In Jesus wonderful name", that is rendered as "Dalam nama Yesus yang ajaib" in turn 8. The preacher's utterance in turn 7 above has the construction of a prepositional phrase, and so does the interpreter's rendition in turn 8 . Comparing (8) with (7), it highlights the level of similarity between the original and the rendition in terms of the propositional content.

The interpreter output in the data above shows that close renditions may occurred because the preacher's utterances are short and simple, in which short and simple utterances were easier and do not take as much time to reproduce, than longer or complex utterances. In addition, the preacher message is conveyed with a clear flow of thought, making it easier for the interpreter to grasp the message, and has enough time to structure his output as close as possible to the original utterances.

\section{Expanded renditions}

Expanded renditions refer to interpreters output in which the information included in the rendition is more explicit than the preceding original utterance (Wadensjö, 1998:107). The interpreters output in this study shows that some of the original utterances in the data are expanded for the purpose of clarity, to make the implied information explicit, to add cohesion, or to clarify the message by encoding visual information.

\section{Excerpt 2 (Sermon 4, minutes 07:50 - 08:07)}

\section{$1 \mathrm{PR}$ : Amen, blessed the God of the Holy} word

2 INT : Inilah firman Tuhan yang kudus, amin

3 PR : This morning I want to talk the armor of God

4 INT : Pagi hari ini saya mau berbicara tentang senjata, perlengkapan senjata Allah

$5 \mathrm{PR}$ : The first thing we need to realize that this is God's armor

6 INT : Yang penting kita harus tahu ini perlengkapan senjatanya Allah, bukan

\section{perlengkapan senjatanya kita}

Excerpt 2 contains an example of expanded renditions produced by the interpreters in the data. As we can see, in turn 5, the preacher says "The first thing we need to realize that this is God's armor", and then it is rendered by the interpreter in turn 6 as "Yang penting kita harus tahu bahwa ini perlengkapan senjatanya Allah, bukan perlengkapan senjatanya kita". The preacher's utterance in turn 5 above is a complex sentence that has the construction consisted of an adverbial (The first thing), subject (we), predicate (need to realize), object (that this is God's armor). Whereas, the rendition in turn 6 consisted of an adverbial (Yang penting), subject (kita), predicate (harus tahu), object (ini perlengkapan senjatanya Allah), object (bukan perlengkapan senjatanya kita). Therefore, comparing the interpreter's rendition in turn 6 to the original in turn 5 , it shows that the rendition is more explicit that the original, indicated by the addition of the phrase "bukan perlengkapan senjatanya kita" after the close rendition "Yang penting kita harus tahu ini perlengkapan senjatanya Allah". The close rendition "Yang penting kita harus tau bahwa ini perlengkapan senjata Allah" is actually quite acceptable, yet the interpreter resorts to expand his rendition due to the purposes of clarity.

The interpreter might feel the need to expand his rendition in order to make sure the congregation understands what the preacher says. The interpreter probably perceives that if the original utterance above is interpreted with a close rendition, the congregation may not necessarily grasp the intended message conveyed by the preacher. The congregation might think that the armor of God is the same as the physical armor worn by human beings in battles. In fact, the preacher used the biblical concept of God's armor figuratively to signify the various elements used by God in the spiritual battle with the Devil. So, in order not to confuse the congregation, he expands his rendition, even though the addition makes him more visible in his output. 


\section{Reduced renditions}

Reduced renditions refer to interpreters output in which the rendition includes less explicitly expressed information than the preceding original utterance (Wadensjö, 1998:107). The interpreters output in the data of this study shows that some of the original utterances have been reduced due to timeconstraints, lack of memory capacity, in order to save time.

Excerpt 3 (Sermon 5, minutes 03:30 - 04:10)

$1 \mathrm{PR}$ : A lot of Australians come to Bali

2 INT : Banyak orang Australia datang ke Bali

3 PR : But very few people from Bali come to Australia

4 INT : Tapi sedikit orang Bali pergi ke Australia

5 PR : Do you realize that we have the largest wild horse population in the world?

6 INT : Tahukah saudara bahwa Australia memiliki yaitu populasi kuda liar yang terbanyak di seluruh dunia?

7 PR : The largest wild donkey population in the world?

8 INT : Dan juga keledai?

$9 \mathrm{PR}$ : The largest wild goat population in the world?

10 INT : Kambing yang paling banyak di dunia?

Excerpt 3 contains examples of reduced renditions produced by the interpreters in the data. As we can see, in turn 7 , the preacher says "The largest wild donkey population in the world?", and then it is rendered by the interpreter in turn 8, as "Dan juga keledai?". The original utterance in turn 7 above is basically an interrogative sentence consisted of noun phrase that serves as an object. This utterance is then rendered by the interpreter in turn 8 as "Dan juga keledai?" that has the construction consisted of a noun phrase that also serves also as an object. Nevertheless, comparing (8) with (7), it shows that the interpreter has omitted the phrases "The largest wild" and "population in the world" that are explicitly expressed in the original. The original utterance above should have been rendered as "Populasi keledai liar yang paling banyak di dunia".

Next, in turn 9, the preacher says "The largest wild goat population in the world", and then it is rendered by the interpreter in turn 10 as "Kambing yang paling banyak di dunia". Therefore, comparing (10) with (9), it shows that the interpreter's rendition above is also less explicit than the original. In this case, the interpreter omits the adjective "wild" and the noun "population", in which the complete rendition of the original above should has been "Populasi kambing liar yang paling banyak di dunia". Since the interpreter's output lacks certain elements of the original utterances, thus might result in the distortion of the original messages.

The interpreter's output in the data above shows that the reduced rendition may occur due to time constraint. The interpreter might be forced to reduce his renditions considerably because of his inability to accommodate the length of utterances and the level of speed at which the speeches are delivered. In such a case, the interpreter may have to manage information by selecting what needs to be interpreted and reproducing the most important parts or the core message of the original in order to save time.

\section{Substituted renditions}

Substituted renditions refer to interpreters output consisting of a combination of an expanded and a reduced utterance (Wadensjö, 1998:107). It implies that the information contained in the original utterance has been replaced or changed in the rendition. Interpreters output in the data of this study shows that substituted renditions may occurred due to the lack of understanding.

Excerpt 4 (Sermon 2, minutes 23:01 - 23:22)
1 PR : Number three
2 INT : Yang ke tiga saudara 
3 PR : Some people believe

4 INT : Beberapa orang percaya

$5 \mathrm{PR}$ : That failure is objective

6 INT : Bahwa kegagalan itu seperti tembok yang tebal

7 PR : Failure is not objective

8 INT : Kegagalan bukan, saudara

$9 \mathrm{PR}$ : It is a choice you have to make

10 INT : Itu adalah keputusan yang saudara harus buat

Excerpt 4 contains an example of substituted renditions produced by the interpreters in the data. As we can see, in turn 5, the preacher says, "That failure is objective", and it is rendered by the interpreter in turn 6 as "Bahwa kegagalan itu seperti tembok yang tebal". The preacher's utterance in turn 5 is basically a sub-sentence consisted of a conjunction (That), subject (failure), verb (is), object (objective). This utterance is rendered by the interpreter in turn 6 that has the construction consisted of a conjunction (Bahwa), subject (kegagalan itu), object (seperti tembok yang tebal). Therefore, comparing the interpreter's rendition in turn 6 above to the original it shows the original utterance has been substituted in the rendition. In this case, the interpreter substituted the word "objective" into the phrase "seperti tembok yang tebal". The adjective "objective" in the original utterance above should actually has been rendered as "objektif, obyektif" or with a descriptive equivalent "tidak bisa diubah", so that the rendition becomes "bahwa kegagalan itu tidak bisa diubah" or "kegagalan itu sifatnya obyektif". Yet, the interpreter prefers to use the phrase "seperti tembok yang tebal", that has different meaning, or misinterpreted. This, in turn, will obviously negatively affect the message conveyed by the preacher or misleading, because the congregation who are completely reliant on the interpreter received a distorted message.

The interpreter's output in the data above shows that the substituted rendition may occur due to the lack of understanding. This is probably because the original utterance is incomprehensible to the interpreter, since it contains a term that the interpreter is not familiar with. In such a case, the interpreter resulted to use of approximate strategy that did not communicate the message in target language. By using this approximate of "seperti tembok yang tebal", the meaning is distorted.

\section{Summarized renditions}

Summarized renditions refer to interpreters output that correspond to two or more prior originals. In some cases, the interpreter summarized two or more 'originals' provided by one or the same interlocutor. In other cases, the 'summarized rendition' corresponds to two or more utterances voiced by different individuals (Wadensjö, 1998:107-108). The interpreters output in the data of this study shows that summarized renditions may occurred due to lexical difficulties, lack of understanding.

Excerpt 5 (Sermon 4, minutes 09:34 - 09:55)

$1 \mathrm{PR}$ : You and I have an enemy

2 INT : Saudara dan saya juga punya musuh

$3 \mathrm{PR}$ : And that's the satan and its demon spirits

4 INT : Yaitu setan dan roh-roh jahatnya

$5 \mathrm{PR}$ : And because satan is a spirit

6 INT : Sebab setan adalah roh

7 PR : He does not rest

$8 \mathrm{PR}$ : He doesn't rest

9 INT : Dia tidak membangkitkan

$10 \mathrm{PR}$ : He'll attack you day and night

11 INT : Oh dia tidak rest, oh dia tidak istirahat, tetapi dia lembur menyerang saudara siang dan malam

Excerpt 5 contains an example of summarized renditions produced by the interpreters in the data. As we can see, in turn 10, the preacher says, "He'll attack you day and night', and then it is rendered by the interpreter in turn 11, as "Oh dia tidak rest, oh dia tidak rest, tetapi dia lembur menyerang saudara". The preacher's utterance in turn 10 above is basically a simple sentence that has the construction consisted of a subject (He), predicate (will attack), object (you), adverbial (day and night). 
This original utterance is then rendered by the interpreter in turn 11 as a complex sentence "Oh dia tidak rest, oh dia tidak rest, tetapi dia lembur menyerang saudara" that has the construction consisted of an interjection (Oh), subject (dia), predicate (tidak istirahat); coordinate conjunction (tetapi), subject (dia), complement (lembur), predicate (menyerang), object (saudara), adverbial (siang dan malam). Comparing the interpreter's rendition in turn 11 above to the preceding original utterances, it shows that the interpreter summarizes two separate original utterances of the preacher in turns 8 and 10 into one output in turn 11. Consequently, the interpreter becomes more visible in his output.

The interpreter's output in the data above shows that the summarized renditions may occur due to lexical difficulty. The above discourse indeed reflects the interpreter's struggle to comprehend the original utterance, in particular the word "rest" in turn 7, as indicated by the repetition of the original utterance in turn 8 , and the mistake "membangkitkan" committed by the interpreter in turn 9. Hence, to recover it, he finds it more appropriate to convey the message in the form of a summarized rendition so that the congregation could comprehend the meaning.

\section{Two part or multi-part renditions}

Two-part renditions refer to two interpreter's utterances corresponding to one original, which is split into parts by another interjected original utterance, the propositional content of which is not reflected in the rendition (Wadensjö, 1998:108). The interpreters output in the data of this study shows that two part renditions may occurred due to overlapping.

\section{Excerpt 6 (Sermon 1, minutes 37:53 - 38:37)}

1 PR : That's how much, that's how much your God loves you

2 INT : Itulah seberapa besarnya Tuhan mengasihi saudara

3 PR : When you are in the middle of the test, God says, I asked and sent someone to encourage you in your test

\section{INT : Waktu saudara sedang dalam pencobaan, Tuhan kirimkan \\ 5 PR : That's the God you serve

$6 \mathrm{INT}:$ Orang-orang yang akan
menyemangati saudara
$7 \mathrm{PR} \quad$ : Hallelujah.

Excerpt 6 contains an example of twopart renditions produced by the interpreters in the data. As we can see, in turn 3, the preacher says, "When you are in the middle of the test, God says, I asked and sent someone to encourage you in your test", and then it is rendered by the interpreter in turns 4 as "Waktu saudara sedang dalam pencobaan Tuhan kirimkan". The preacher's utterance in turn 3 above is a complex sentence that has the construction consisted of an adverbial (When you are in the middle of the test), subject (God), predicate (says), complement (I asked and sent someone to encourage you in your test). This original utterance is then rendered by the interpreter in turn 4, as "Waktu saudara dalam pencobaan, Tuhan kirimkan", consisted of an adverbial (Waktu saudara sedang dalam pencobaan), subject (Tuhan), predicate (kirimkan).

Next, in turn 5, the preacher says "That's the God you serve", followed by the interpreter's rendition in turn 6 as "Orang-orang yang akan menyemangati saudara". The preacher's utterance in turn 5 is a simple sentence consisted of a subject (That), predicate (is), object (God), complement (you serve). While, the rendition in turn 6 is a noun phrase "Orang-orang yang akan menyemangati saudara", that serves as a complement. Therefore, comparing then interpreter's renditions in turns 4 and 6 to the preceding originals in turns 3 and 5, it shows that the interpreter's renditions in turns 4 and 6 correspond to one original utterance in turn 3 , which is split into two parts due to another original in turn 5. Meanwhile, the preacher's utterance in turn 5 "That's the God you serve", is left untranslated.

The interpreter's output in the data above shows that two-part renditions may occurred due to overlapping. This happens because the 
preacher continues speaking despite realizing that the interpreter is still interpreting. The interpreter could have started conveying his rendition and unexpectedly interrupted by another original utterance. The interpreter, as might be expected, finds it difficult to accommodate the preacher's utterances at the same time. On such an occasion, the interpreter may have to manage the information by selecting what needs to be interpreted.

\section{Non renditions}

Non renditions refer to interpreters output which is analyzable as an interpreter's initiative or response and does not correspond to any utterances in the source text (Wandesjö, 1998:108). The interpreters output in the data of this study shows that non renditions may occurred as a result of interpreter's autonomous contribution or initiative, such as requests for clarification, comments explaining the intention of the interlocutor, and repetition.

Excerpt 7 (Sermon 5, minutes 08:52 - 09:44)

$1 \mathrm{PR}$ : And if you want your wife to look at you with stars in her eyes

2 INT : Dan kalau kau ingin dia melihat kepadamu dengan bintang di matanya

3 PR : You give her some economic security 4 INT : Berikan kepada dia yaitu keamanan ekonomi

5 INT : Para wanita tepuk tangan dong (.)

katakan "yes"

6 PR : Now you have to ask, how much economic security is enough for a woman?

7 INT : Dan saudara tanya (.) keamanan (.) kestabilan ekonomi jumlah berapa yang cukup untuk seorang wanita?

Excerpt 7 contains an example of non renditions produced by the interpreters in the data. As we can see, in turn 3, the preacher says "You give her some economic security". This original utterance is rendered by the interpreter in turn 4 as "Berikan kepada dia yaitu keamanan ekonomi". Next, in turn 5, the interpreter proceeds by saying "Para wanita tepuk tangan dong (.) katakan "yes", but it has no counterpart in the preceding original. Comparing the interpreter's utterance in turn 5 above to the preceding original, it shows that the interpreter's utterance in turn 5 above is not a rendition of the preceding original, but the result of his own initiative. Consequently, the interpreter's level of visibility becomes more apparent. The interpreter becomes visible.

We could argue that here the interpreter simply made a mistake or against the norm stating that interpreters should just translate. But if we look from different perspective, we may understand that the interpreter attempted to fill his role as a mediator by displaying his understanding of the preacher's intention not only rely on linguistic information, but also based on context of interaction, by speaking directly with the congregation to respond to the preacher's utterances, as an attempt to keep the congregation' attention alert.

\section{Zero renditions}

Zero renditions refer to interpreters output in which the original utterances are left untraslated (Wandesjö, 1998:108). The interpreters output in the data of this study shows that zero-renditions may occurred for several reasons, such as it is deemed unimportant or irrelevant, repetition, misses the original utterance, already clear from context.

Excerpt 8 (Sermon 4, minutes 05:24 - 05:36)

$1 \mathrm{PR}$ : Good, and I'll be reading from verse number ten

2 INT : Saya membaca mulai ayat 10

3 PR : Finally, my brethren, be strong

4 INT : Akhirnya, hendaklah kamu kuat dalam Tuhan

$5 \mathrm{PR}$ : My Bible is falling to pieces, so I just gonna get it ready

6 PR : Ok, finally, my brethrens, be strong in the Lord, and in the power of his might.

Put on the whole armor of God, that ye may be able to stand against the wiles of the devil. ... 
7 INT : Akhirnya, hendaklah kamu kuat di dalam Tuhan, di dalam kekuatan kuasa-Nya. Kenakanlah seluruh perlengkapan senjta Allah, supaya kamu dapat bertahan melawan tipu muslihat iblis

Excerpt 8 contains an example of zero renditions produced by the interpreters in the data. As we can see, in turn 5, the preacher says "My Bible is falling to pieces, so I just gonna get it ready", but it has no counterpart in the interpreter's output. Comparing the preacher's utterance in turn 5 to the following turn of the interpreter, it shows that the original in turn 5 is left untranslated by the interpreter. The original in turn 5 above should actually have been rendered as "Kertas Alkitabnya terlepas, karena itu saya akan mengaturnya dulu", yet the interpreter decides not to render it. Consequently, the congregation who are completely reliant on the in interpreter could not access the message conveyed by the preacher.

The reason for this might be that the interpreter perceives the preacher's original utterance in turn 5 is deemed unnecessary, as the preacher's comment in turn 5 is just a remark that is not directly related to the Scripture passage that is going to be read by the preacher. Moreover, when conveying the utterance, the preacher faced directly to the interpreter indicating that the interpreter should pause interpreting for a while, and therefore needs not to be interpreted to the congregation.

\section{CONCLUSION}

This paper has discussed the renditions produced by the interpreters in sermon interpreting at ROCK Church Denpasar Bali. The main focus of this paper has been on discussing the categories of rendition and the motives of the occurrence of the renditions produced by the interpreters.

Based on the data analyses, the results show that of the eight categories of rendition proposed by Wadensjö (1998) in her taxonomy of renditions, all of them were identified in the data, with the exception that there are fewer examples of summarized renditions, and two-part renditions found on the data because the data had monological characteristics and the interpreters did not engaged much interaction management during the communicative event. Overall, the categories of rendition identified in the data are close renditions, expanded renditions, reduced renditions, substituted renditions, summarized renditions, two-part renditions, non-renditions, and zero renditions.

There are a number of different motives or factors that contributed to the production of these renditions. In close renditions, the interpreters may produce close renditions because the original utterances are short and simple. In expanded renditions, some of the original utterances in the data are expanded for the purpose of clarity, to make the implied information explicit, to add cohesion, or to clarify the message by encoding visual information. In reduced renditions, some of the original utterances in the data have been reduced due to time-constraints, lack of memory capacity, in order to save time. In substituted renditions, they may occur due to lack of understanding. In summarized renditions, they may occur due to lexical difficulties. In two-part or multy-part renditions, they may occur due to overlapping. In non-renditions, they may occur as a result of interpreter's autonomous contribution or initiative as a mediator, such as requests for clarification, comments explaining the intention of the interlocutor, and repetition. While, in zero renditions, some of the original utterances are left untranslated due to several reasons, such as it is deemed unimportant or irrelevant, repetition, and misses the original utterance.

Analyzing the motives of the renditions produced by the interpreters in the data, it reveals that the interpreters do make different decisions about their interpretation choices based not only on the propositional content of the original utterances, but also on the context of interaction. Therefore, judgments of accuracy should be made based not only on the preceding originals, 
but also on the wider context of the whole interaction. It is to say that some of the situations that contribute to incomplete communication during interpretation or deviation from the original utterances do have a number of implications and effects to the quality of interpretation. While, on the other hand, some of the deviation from the original utterances appeared to be alternative interpreting strategies applied by the interpreters to deal with specific challenges in interpreting or in regard to what needed to be done in the interaction. The findings of this study support Wadensjö's (1998) research with dialogue interpreters.

\section{REFERENCES}

Hatim, B and Munday. (2004). Translation: An Advanced Resource Book. London: Routledge.

Moleong, L J. 2004. Metodologi Penelitian Kualitatif. Bandung: PT Remaja Rosdakarya.

Pöchhacker, F. (2004). Introducing Interpreting Studies. New York: Routledge

Olohan M. Introducing Corpora in Translation Studies

Sudaryanto. (1993). Metode dan Aneka Teknik Analisis Bahasa. Jakarta: Duta Wacana University Press.

Wadensjö, C. (1998). Interpreting as Interaction. England: Addison Wesley Longman Limited 